УдК 616.89-008.454

DOI 10.11603/2411-1597.2019.4.10834

\title{
ДЕПРЕСІЯ ЯК ОДИН З ЧИННИКІВ, ЩО СПРИЯЮТЬ РОЗВИТКУ ПСИХОСОМАТИЧНИХ РОЗЛАДІВ
}

\author{
Н. О. Рештакова \\ КЗОЗ «Обласна клінічна психіатрична лікарня М. Слов'янська» \\ Тернопільський національний медичний університет \\ імені І. Я. Горбачевського МОЗ Украӥни
}

У статті проаналізовано механізм розвитку психосоматичних захворювань, а також депресія як чинник, що сприяє виникненню психосоматичних розладів.

\section{DEPRESSION AS ONE OF THE CONTRIBUTING FACTORS TO THE DEVELOPMENT OF PSYCHOSOMATIC DISORDERS}

\author{
N. O. Reshtakova \\ Regional Clinical Psychiatric Hospital in the city Slovyansk \\ I. Horbachevsky Ternopil National Medical University
}

The article analyzes the mechanism of development of psychomatic diseases, and depression as a factor contributing to the emergence of psychosomatic disorders.

Вступ. Психічні хвороби уражають людей незалежно від їх приналежності та економічного добробуту. Одним із пріоритетів нашої країни є покращення психічного здоров'я та соціального функціонування осіб, які страждають від психічних розладів.

Термін «психосоматичний» походить від грецьких слів психіка та сома. Психосоматичні захворювання - це група хворобливих станів, що з'являються у результаті взаємодії психічних і фізіологічних чинників. Психосоматичні розлади являють собою психічні розлади, що проявляються на фізіологічному рівні або можуть розвиватися під впливом психогенних чинників [3]. Якщо фізіологічні розлади проявляються на психічному рівні, то такі стани є соматопсихічні. Термін «психосоматика»вперше запропонував у 1818 р. J. Heinroth, який вважав психогенними багато соматичних хвороб, особливо в етичному аспекті. Через 10 років М. Якобі ввів протилежне поняття «соматопсихічні хвороби», яке доповнювало «психосоматичні хвороби». На сьогодні цей термін має два значення, пов'язані з його застосуванням у медицині та хворобами, в патогенезі яких важливу роль відіграють психологічні, психовегетативні

$\overline{\text { (c) Н. О. Рештакова, } 2019}$ чинники та й особистість. Психосоматичні розлади включають не лише психосоматичні захворювання в традиційному, вузькому, розумінні цього терміна, але й значно ширше коло порушень - соматизовані розлади, патологічні психогенні реакції на соматичні захворювання та інше, а також психічні розлади, що часто ускладнюються соматичною патологією.

У нормі взаємовплив психіки та соми найвираженіше проявляється під час емоційних реакцій: радощів, гніву, страху тощо. Якщо людина занадто схвильована, кажуть: «стиснулося серце», «підкотив клубок до горла», «став білим, мов крейда» або «почервонів як рак», «мов камінь з душі» тощо. Усі ці образні висловлювання вказують на соматичні зміни, що виникають під час емоційних переживань. При цьому спостерігають психосоматичні відхилення від емоційного компонента [5].

Традиційно ми вважаємо розум (психіку) і тіло (сома) окремими, але де і як вони взаємодіють? Як відповідь, основне поняття було описано 3. Фрейдом, який використовував термін «конвертаційна істерія», що $\epsilon$ не що інше, як зміна експресивної поведінки, тобто від невирішеної емоції до соматичного симптому. 
Причини значного зростання числа хронічних захворювань тісно пов'язані з психологічним станом населення. У наш час практично кожна людина відчуває хронічне перенапруження, яке супроводжується пригніченим настроєм, тривогою, погіршенням сну. Психічні розлади та соматичні захворювання впливають на функціональний стан людини.

Основна частина. Згідно з даними експертів ВОО3, майже 50 \% стаціонарних лікарняних ліжок у світі займають пацієнти з психосоматичною патологією [1].

Один із чинників виникнення психосоматичних захворювань це депресія, яка сприяє розвитку ряду таких захворювань, як гіпертонічна хвороба, вегетосудинна дистонія, нейродерміт, мігрень та ін.

Соматичні захворювання, зумовлені психогенними чинниками, називають психосоматичними розладами. Це захворювання, причинами яких здебільшого $\epsilon$ розумові процеси хворого ніж безпосередньо будь-які фізіологічні причини. Якщо медичне обстеження не може виявити фізичну або органічну причину захворювання, або якщо захворювання $\epsilon$ результатом таких емоційних станів, як гнів, тривога, депресія, відчуття провини, тоді хвороба може бути класифікована як психосоматична [2].

Тіло і розум впливають один на одного і працюють як одиниця. Кожне фізичне захворювання має певний аспект психічної складової, і те, як людина реагує та справляється з ним, істотно змінюється.

Показано вплив депресії як чинника, який збільшує ризик багатьох захворювань, наприклад серцевосудинних, інсульта, діабету та ожиріння [6].

у багатьох дослідженнях одним із провідних чинників розвитку психосоматичної патології вважають депресію. Депресія - це захворювання, що характеризується постійним пригніченим станом та втратою цікавості до будь-якої діяльності, що зазвичай приносить задоволення, а також нездатністю виконувати повсякденні справи протягом як мінімум двох тижнів. До симптомів депресії належать:

- поганий настрій, який триває більше двох тижнів і не залежить від зовнішніх обставин;

- зниження або втрата здатності отримувати задоволення, втрата мотивації до діяльності;

- підвищена стомлюваність, занепад сил, які тривають більше двох тижнів;
- почуття провини, страху, тривоги, власної непотрібності;

- порушення сну (безсоння або гіперсомнія - патологічна сонливість);

- зниження або підвищення апетиту, втрата маси тіла;

- негативні переконання щодо себе або стосунків із оточуючими;

- втрата уваги - зниження здатності до концентрації;

- суїцидальні думки [4].

Крім цього, для виявлення симптомів депресії використовують різні опитувальники та шкали. Наприклад, для скринінгу депресії у пацієнтів групи ризику застосовують Опитувальник здоров'я пацієнта PHQ-2 (Patient Health Questionnaire). При позитивній відповіді хоча 6 на одне запитання PHQ-2 проводять подальше опитування з використанням опитувальника PHQ-9. У разі підтверджувальної суми балів уточнюють особливості перебігу депресії, що в цілому дозволяє встановити синдромальний діагноз депресії та визначити її тяжкість [7].

Для остаточного вирішення питання встановлення діагнозу психосоматичного розладу необхідно провести диференційну діагностику задля виключення інших патологічних станів та призначити правильне симптоматичне лікування. Розрізняють такі диференційно-діагностичні критерії, за допомогою яких можна припустити наявність психосоматичного захворювання:

- атиповість клінічних проявів;

- невідповідність клінічних проявів результатам об'єктивного параклінічного обстеження;

- неефективність лікування соматоневрологічної патології [8].

Висновки. Проблема психосоматичних співвідношень - одна з найскладніших проблем сучасної медицини, незважаючи на те, що тісний взаємозв'язок психічного та соматичного здоров'я помічений і вивчається протягом багатьох століть, з часів Гіппократа й Арістотеля.

Дуже складно визначити психосоматичний чинник виникнення захворювання. Це допоможе збільшити ефективність лікування, сформує правильну тактику в спілкуванні з хворим. Допоможе пацієнту звернути увагу на психологічні проблеми. 


\section{СПИСОК ЛІТЕРАТУРИ}

1. Доклад о состоянии здравоохранения в Европе // Новости медицины и фармации. - 2002. - № 1-2. - С. 5-6.

2. Погорєлов І. І. Психіатрія і наркологія : підручник / І. І. Погорєлов, О. Д. Манаєнкова. - 2-ге вид. - К. : ВСВ «Медицина», 2018. - 157 с.

3. Степанов Ю. М. Психосоматические аспекты и функциональные заболевания желудочно-кишечного тракта / Ю. М. Степанов // Здоров'я України. - 2008. № 19/1. - C. 32-33.

4. URL : http://kmarehab.org/2019/03/06/depression/.

5. URL : https://pidruchniki.com/76717/meditsina/ psihosomatichni_somatopsihichni_rozladi.

6. Chronic pain, depression and cardiovascular disease linked through a shared genetic predisposition: Analysis of a family-based cohort and twin studi / O. Van Hecke, L. Hochking, N. Torrance [et al.] // PLoS ONE. - 2017. -Vol. 12(2). P. 0170653 . DOI : 10.1371/journal.pone.01700653.

7. Депресія (легкий, помірний, тяжкий депресивні епізоди без соматичного синдрому або з соматичним синдромом, рекурентний депресивний розлад, дистимія : Уніфікований клінічний протокол первинної, вторинної (спеціалізованої) та третинної (високоспеціалізованої) медичної допомоги (УКПМД)». - 14 с.

8. Медсестринство в психіатрії / О. С. Чабан, В. В. Дегтяр, С. В. Білоус та ін. - Тернопіль : Укрмедкнига, 2001. - 264 с.

Отримано 07.11.19 